University of Nebraska - Lincoln

DigitalCommons@University of Nebraska - Lincoln

Daugherty Water for Food Global Institute:

Faculty Publications

Daugherty Water for Food Global Institute

2020

Ferrihydrite Reduction Increases Arsenic and Uranium

Bioavailability in Unsaturated Soil

Arindam Malakar

Michael Kaiser

Daniel D. Snow

Harkamal Walia

Banajarani Panda

See next page for additional authors

Follow this and additional works at: https://digitalcommons.unl.edu/wffdocs

Part of the Environmental Health and Protection Commons, Environmental Monitoring Commons, Hydraulic Engineering Commons, Hydrology Commons, Natural Resource Economics Commons, Natural Resources and Conservation Commons, Natural Resources Management and Policy Commons, Sustainability Commons, and the Water Resource Management Commons

This Article is brought to you for free and open access by the Daugherty Water for Food Global Institute at DigitalCommons@University of Nebraska - Lincoln. It has been accepted for inclusion in Daugherty Water for Food Global Institute: Faculty Publications by an authorized administrator of DigitalCommons@University of Nebraska Lincoln. 
Authors

Arindam Malakar, Michael Kaiser, Daniel D. Snow, Harkamal Walia, Banajarani Panda, and Chittaranjan Ray 


\title{
Ferrihydrite Reduction Increases Arsenic and Uranium Bioavailability in Unsaturated Soil
}

\author{
Arindam Malakar, ${ }^{1}$ Michael Kaiser, ${ }^{2}$ Daniel D. Snow, ${ }^{3}$ \\ Harkamal Walia, ${ }^{2}$ Banajarani Panda, ${ }^{4}$ \\ and Chittaranjan Ray ${ }^{1}$
}

\begin{abstract}
1 Nebraska Water Center, part of the Robert B. Daugherty Water for Food Global Institute, University of Nebraska, Lincoln, Nebraska 68583-0844, United States

2 Department of Agronomy, University of Nebraska, Lincoln, Nebraska 68583-0915, United States

3 School of Natural Resources and Nebraska Water Center, Robert B. Daugherty Water for

Food Global Institute, 202 Water Sciences Laboratory, University of Nebraska, Lincoln, Nebraska 68583-0844, United States

4 Department of Earth and Atmospheric Sciences, University of Nebraska, Lincoln, Nebraska 68588- 0340, United States; Department of Earth Sciences, Annamalai

University, Annamalai Nagar 608002, India

Corresponding author - Chittaranjan Ray, Nebraska Water Center, Robert B. Daugherty Water for Food Global Institute, University of Nebraska, Lincoln, Nebraska 68588-6204, United States; email cray@nebraska.edu
\end{abstract}

\section{ORCID}

Arindam Malakar https://orcid.org/0000-0001-6704-8891 Chittaranjan Ray https://orcid.org/0000-0002-1731-2030

\begin{abstract}
Redox driven mobilization and plant uptake of contaminants under transiently saturated soil conditions need to be clarified to ensure food and water quality across different irrigation systems. We postulate that solid-phase iron reduction in anoxic microsites present in the rhizosphere of unsaturated soil is a key driver for
\end{abstract}

Published in Environmental Science \& Technology 54 (2020), pp 13839-13848.

https://dx.doi.org/10.1021/acs.est.oc02670

Copyright (c) 2020 American Chemical Society. Used by permission.

Submitted April 27, 2020; revised September 1, 2020; accepted October 12, 2020;

published October 21, 2020. 
mobilization and bioavailability of contaminants under nonflooded irrigation. To clarify this, two major crops, corn and soybean differing in iron uptake strategies, were grown in irrigated synthetic soil under semiarid conditions with gravimetric moisture content $\sim 12.5 \pm 2.4 \%$. 2-line ferrihydrite, which was coprecipitated with uranium and arsenic, served as the only iron source in soil. Irrespective of crop type, reduced iron was detected in pore water and postexperiment rhizosphere soil confirming ferrihydrite reduction. These results support the presence of localized anoxic microsites in the otherwise aerobic porous bulk soil causing reduction of ferrihydrite and concomitant increase in plant uptake of comobilized contaminants. Our findings indicate that reactive iron minerals undergo reductive dissolution inside anoxic microsites of primarily unsaturated soil, which may have implications on the mobility of trace element contaminants such as arsenic and uranium in irrigated unsaturated soils, accounting for $55 \%$ of the irrigated area in the US.

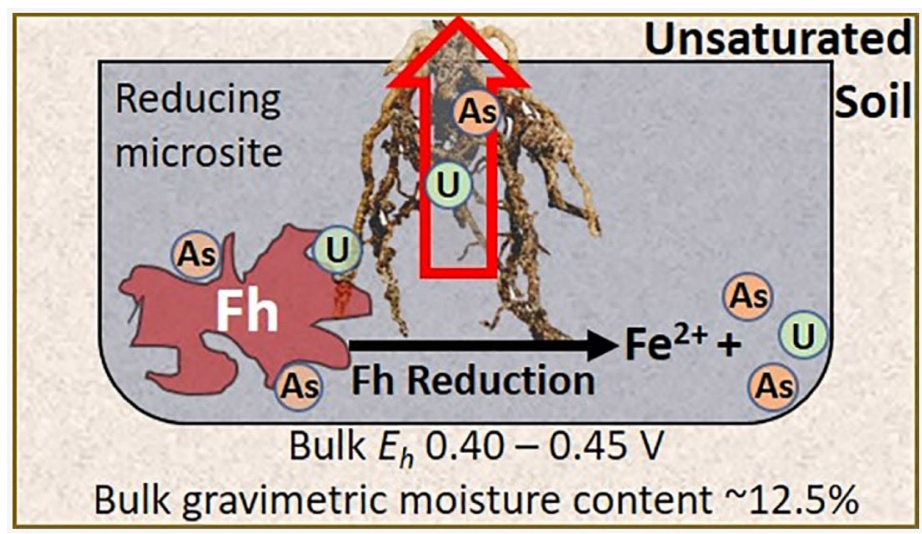

\section{Introduction}

Characterization and mechanistic understanding of nanoscale chemical transformations at the root zone-soil-pore water interface is crucial for safe and efficient food production. These transformations control the plant uptake of essential macro- and micronutrients as well as potentially harmful trace elements (i.e., contaminants). Inorganic contaminants such as arsenic and uranium that occur naturally in soil and water may enter the food chain via plant uptake. ${ }^{1,2}$ Chronic exposure to these trace elements can be responsible for multiple adverse human health effects and is associated with different cancers.3,4 The bioavailability of these geogenic contaminants is closely linked with the biogeochemical cycles of iron..$^{-7}$ Iron itself is an essential and ubiquitous soil micronutrient, which is present in 
the soil in different ionic $\left(\mathrm{Fe}^{2+}, \mathrm{Fe}^{3+}\right)$ and mineral $(\mathrm{Fe}-\mathrm{O} /-\mathrm{OH})$ species. Iron in ionic and mineral forms is known to chemically interact with nutrients and contaminants affecting their mobility and bioavailability. 8,9 Plants take up iron in both ferric $\left(\mathrm{Fe}^{3+}\right)$ and ferrous $\left(\mathrm{Fe}^{2+}\right)$ forms, and the pathway is dependent on soil environmental conditions, ${ }^{10,11}$ whereby especially iron redox events are crucial for shifts in the concentration of colloidal/mineral to ionic iron species. ${ }^{12}$ Among mineral iron species, ferrihydrite (Fh), ${ }^{13-16}$ a transient and highly reactive, redox-sensitive oxidized nanomineral of iron, is of particularly significant importance for the bioavailability of contaminants such as arsenic and uranium in soil..$^{17,18}$

Mobilization of iron-colloid/mineral associated contaminants triggered by iron redox transformation in soil is typically associated with anaerobic conditions, which mainly prevails in flooded and wetland soils. ${ }^{6,19}$ However, in the US, $55 \%$ of irrigated soils remain predominantly unsaturated ${ }^{20}$ because of different crop requirements and irrigation strategies to conserve water. In temporarily saturated conditions at near neutral $\mathrm{pH}$, it is conceived that soil will be aerobic and mainly oxidizing. Therefore, iron will be present mostly in oxidized or ferric form and remain immobile as oxide. ${ }^{21-23}$ However, anoxic microsites can be relevant in transiently saturated rhizosphere soil and can bring about iron reduction. ${ }^{24-29}$ Further, the iron required by crops grown under partially saturated conditions is supplied by rhizosphere processes that trigger iron dissolution at the anaerobic/aerobic root zone-soil-pore water interface. ${ }^{30-32} \mathrm{~A}$ comprehensive understanding of the mechanism of iron minerals redox pathways in irrigated but predominantly unsaturated soil can predict more precisely biogeochemical element cycling and crop performance that can elucidate their effects on nutrient and contaminant mobilization and bioavailability, which is the primary focus of the present work.

Here, we showed that Fh-iron reduction plays a critical role in mobilization and bioavailability of arsenic and uranium at the root zone-soil-pore water interface in predominantly unsaturated soil. This is deduced from the presence of $\mathrm{Fe}^{2+}$ in soil pore water sampled after extended dry periods and the significant increase of phosphorus, dissolved organic carbon (DOC), arsenic, and uranium in pore water along with significantly increased plant uptake of arsenic and uranium. Soil moisture content was maintained similar to 
sprinkler irrigated, semiarid soil of central and western Nebraska, and Fh was the only soil mineralogical source of iron, arsenic, and uranium. Temporally variable, anoxic microsites with distinctly different redox behavior than the bulk soil seem to control biogeochemical cycles of contaminants and can possibly impact nutrient cycling. ${ }^{24-29}$ Therefore, a detailed understanding of reaction pathways of anoxic microsites can help to strategize mechanisms controlling crop growth and trace element contaminants under nonflooding irrigation management.

\section{Materials and methods}

\section{Artificial Soil}

Sand (>99\%) and pure kaolinite powder (200 mesh) were purchased from VWR, USA and were further analyzed for acid digested iron content and dithionite-citrate-bicarbonate extractable iron content, which were found to be $7.7 \pm 3.1 \mathrm{mg} / \mathrm{kg}$ and $2.4 \pm 2.0 \mathrm{mg} / \mathrm{kg}$, respectively, for sand, and $25.2 \pm 2.2 \mathrm{mg} / \mathrm{kg}$ and $15.1 \pm 3.8 \mathrm{mg} / \mathrm{kg}$, respectively, for kaolinite. Iron(III) chloride $\left(\mathrm{FeCl}_{3}\right)$ reagent grade $(97 \%)$, sodium bicarbonate (ACS reagent, >99.7\%, $\mathrm{NaHCO}_{3}$ ), trisodium citrate dihydrate (ACS reagent, $\geq 99 \%$ ), ferrous sulfate (99.9\%), ammonium acetate (99.9\%), acetic acid (99.9\%), calcium carbonate (ACS reagent, $\geq 99 \%$ ), and 1,10-phenanthroline (99.9\%) were purchased from SigmaAldrich, USA. Zinc acetate dihydrate $\left(\mathrm{Zn}\left(\mathrm{CH}_{3} \mathrm{COO}\right)_{2} \cdot 2 \mathrm{H}_{2} \mathrm{O}\right)$ (extra pure, 98\%), cellulose microcrystalline (extra pure, average particle size 90 $\mu \mathrm{m}$ ), sodium hydrosulfite (ca. 85\%, Tech., $\mathrm{Na}_{2} \mathrm{~S}_{2} \mathrm{O}_{4}$ ), and potassium hydroxide $(\mathrm{KOH})$ were manufactured by ACROS organics and purchased from Fisher Scientific, USA. Arsenic (As) and uranium (U) standards were purchased from Inorganic Venture, USA. All water used in the experiment was of reagent grade with resistivity of $18 \mathrm{M} \Omega-\mathrm{cm}$.

\section{Synthesis of 2-Line Ferrihydrite and Coprecipitation with Arsenic and Uranium}

2-line ferrihydrite (Fh) synthesis was carried out following the method described elsewhere.33,34 Briefly, $25 \mathrm{~g}$ of $\mathrm{FeCl}_{3}$ salt was dissolved in $10 \mathrm{~L}$ 
of reagent grade water. Arsenic and uranium standard solutions were added to the Fe-salt mixture. The $\mathrm{pH}$ of this solution mixture was brought to near neutral by controlled addition of $\mathrm{KOH}$, and $\mathrm{pH}$ was kept around $\sim 6.5 \pm 0.2$. Finally, $0.15 \mathrm{~g}$ of $\mathrm{Zn}\left(\mathrm{CH}_{3} \mathrm{COO}\right)_{2} \cdot 2 \mathrm{H}_{2} \mathrm{O}$ was added to change the zeta potential of the solution. The whole mixture was shaken well to precipitate 2 -line Fh. The solution was decanted to reduce volume and filtered. The presolution and postdecants were analyzed for iron, arsenic, and uranium to confirm coprecipitation of the trace contaminants. The precipitate was dried in a vacuum desiccator for $48 \mathrm{~h}$ before use. Multiple batches of synthesis were carried out to produce all of the 2-line Fh required for the greenhouse experiment. Powder XRD (PANalytical Empyrean Diffractometer, $\mathrm{Cu}$ $\mathrm{K}_{\alpha}$ source) was carried out to confirm formation of 2-line Fh (Figure S1), which matches well to the (110) and (115) planes of 2-line Fh (PCPDF\# 29-0712). ${ }^{35}$ ICP-MS was used to quantify the coprecipitation once it was complete, which was $>90 \%$ for both arsenic and uranium.

\section{Greenhouse Experiment}

The different forms of iron hydroxide and oxide minerals in soils can make it complicated to study iron reduction in the root zone. Further, the source of reduced iron can include dissolution of $\mathrm{Fe}^{2+}$ containing minerals, and artificial soil can reduce these environmental complexities. ${ }^{36}$ To address this complex nature of iron minerals, two artificial substrates (i) containing 70\% sand, 27.9\% kaolinite, 2\% cellulose, and $\sim 0.10 \% \mathrm{w} / \mathrm{w}$ (arsenic and uranium adsorbed prequantified) Fh (Soil\#1) and (ii) containing 70\% sand, 27.85\% kaolinite, $2 \%$ cellulose, and $\sim 0.15 \% \mathrm{w} / \mathrm{w}$ Fh (Soil\#2) were prepared. This was done to mimic two different soil mineralogical conditions based on varying contents in dithionite-citrate-bicarbonate (DCB) extractable iron, ${ }^{37}$ arsenic, and uranium, as observed in central and western Nebraska. However, artificial soil may not entirely replicate the actual rhizosphere conditions but can predict rhizosphere phenomena up to a certain extent. Each starting substrate was weighed out and mixed separately for all twelve replicates per soil mixture. Corn $(n=6)$ and soybean $(n=6)$ were grown in each soil mixture for a total of 60 days. Replications for corn and soybean cultivated in the two soil mixtures were randomly distributed in the greenhouse at the University of Nebraska-Lincoln. 
a)

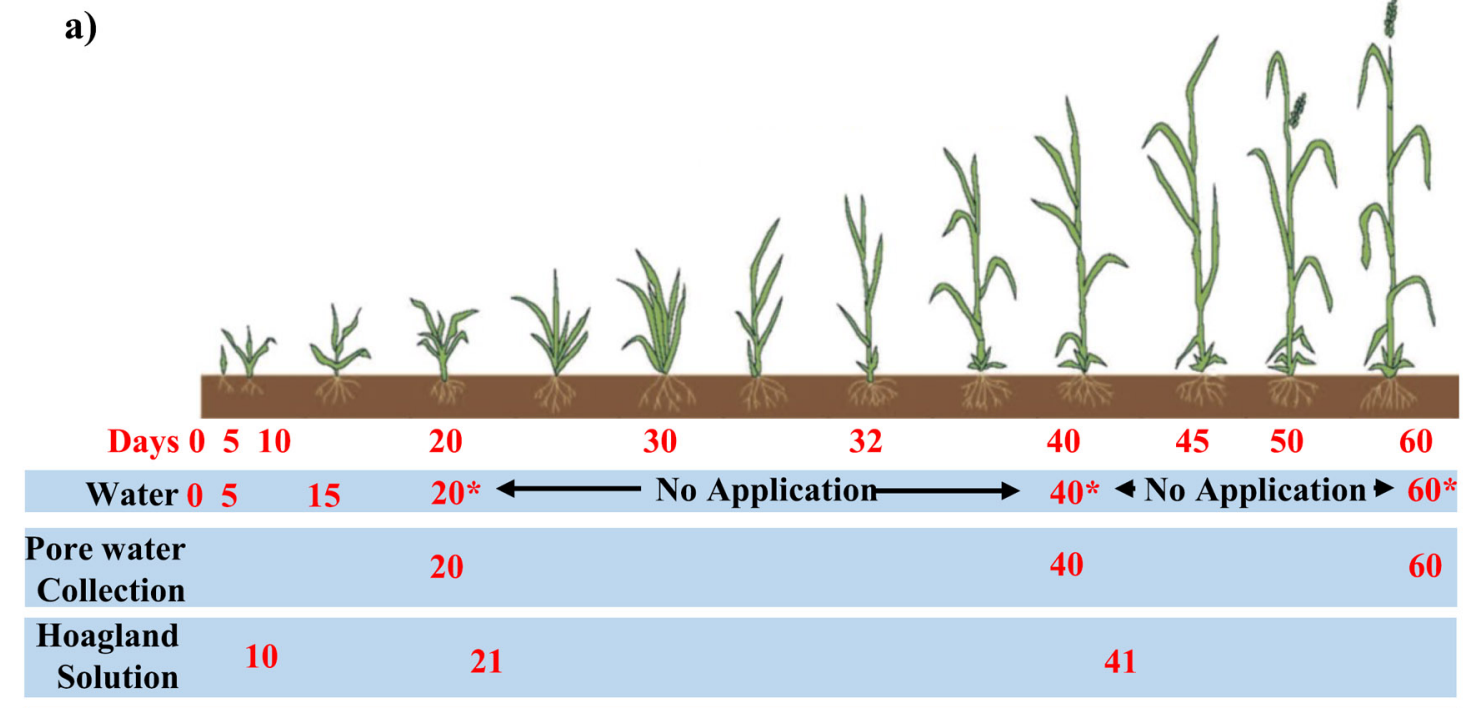

Harvest

*Water application for pore water sample collection
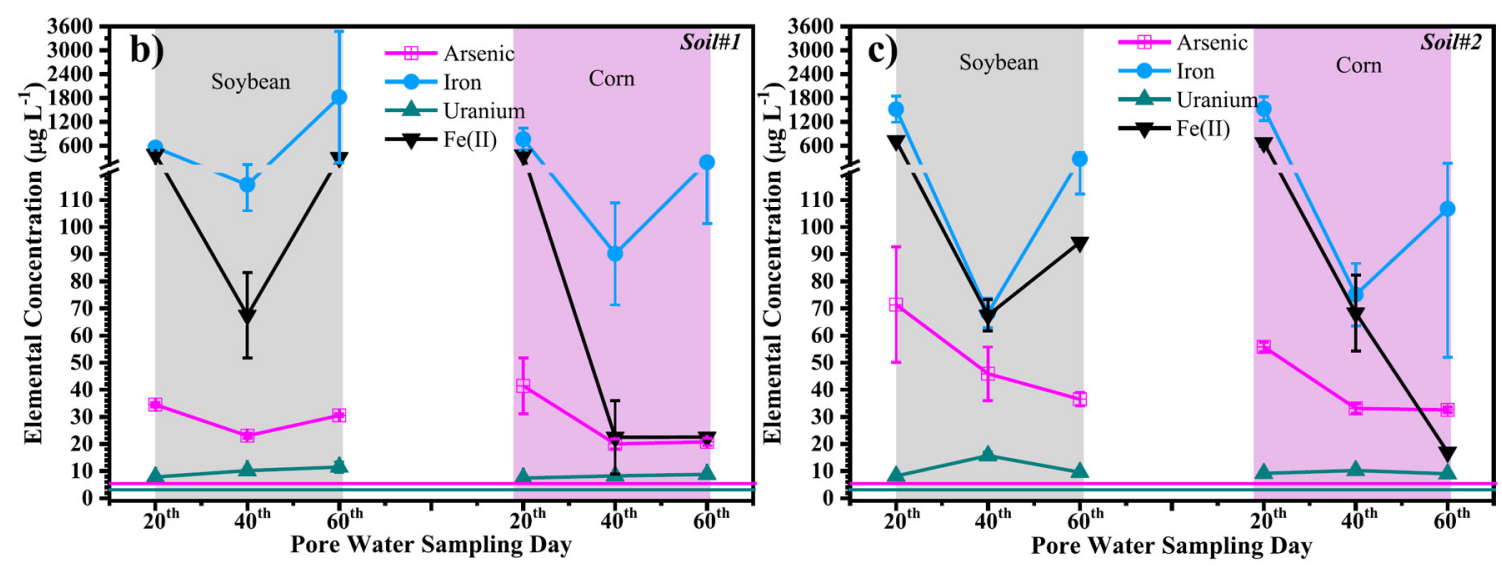

Figure 1. a) Timeline of water application, pore water collection, Hoagland solution application, and harvesting in the greenhouse experiment. b) and c) Concentrations of iron, $\mathrm{Fe}(\mathrm{II})\left(\mathrm{Fe}^{2+}\right)$, arsenic, and uranium in the pore water for Soil\#1 (b) and Soil\#2 (c) for soybean and corn $(n=6)$. The magenta and cyan lines are the concentration of arsenic (5.5 $\left.\mathrm{g} \mathrm{L} \mathrm{L}^{-1}\right)$ and uranium (3.4 $\left.\mathrm{g} \mathrm{L} \mathrm{L}^{-1}\right)$ in artificial irrigation water. Soil\#1 contained less Fh compared to Soil\#2, but irrespective of soil and crop, $\mathrm{Fe}^{2+}$ was observed in the pore water after a prolonged nonirrigated stage in between pore water collections (40th and 60 th day collections). The moisture content was $~ 15 \%$ before the first pore water collection on the 20th day, indicating Fh transformation under unsaturated conditions. Pore water also contained an elevated amount of arsenic and uranium, which varied between 20 and $110 \mu \mathrm{g} \mathrm{L}^{-1}$ and $4-17 \mu \mathrm{g} \mathrm{L}^{-1}$, respectively. 
A control set, without any crops, was also kept in the greenhouse, and samples were collected similarly. However, no signature of reduced iron was observed in the control pots with a negligible amount of arsenic and uranium, and this data will not be discussed further. Pots of $25 \mathrm{~cm}$ diameter received $7 \mathrm{~kg}$ of the soil mixture. The greenhouse temperature was controlled between 22 and $28{ }^{\circ} \mathrm{C}$, and crops received $16 \mathrm{~h}$ of daily light. Soil mixture $\mathrm{pH}$ was maintained at 6.9 to 7.5 by applying lime (Figure S2). The modified Hoagland solution ${ }^{38}$ was prepared which was devoid of iron to supply macro- and micronutrients required for the crop growth (Figure 1a). The Hoagland solution was applied after each pore water collection to replenish essential nutrients required for sustaining crop growth (Figure 1a). Artificial irrigation water containing arsenic and uranium was prepared utilizing arsenic and uranium standard solutions, and the $\mathrm{pH}$ of irrigation water was around $\sim 6.9 \pm 0.1$.

Equal weight of irrigation water was given to each crop, and equal weight of irrigation water was used to collect pore water samples from each pots. Moisture content was maintained at $12.5 \pm 2.4 \%$ (saturated water content was $\sim 24.3 \%$ ) for each pot, before the first leaching of pore water. Soil field capacity moisture content was measured for two soil mixtures before the start of the experiment. Soil moisture content was measured gravimetrically throughout the experiment and before pore water collection events. Pore water from each pot was collected as leachate in a clean tray placed at the bottom of the pot after 20,40, and 60 days of sowing seeds. Equal weight (900 g) of artificial irrigation water was added in each pot, and within $30 \mathrm{~min}$, leachate was collected in the tray. After each pore water sample collection event, plants were only supplied with $100 \mathrm{~g}$ of the Hoagland solution to replenish essential nutrients which were lost during pore water collection. Plants were not watered again until the next pore water sampling event, as unsaturated conditions were fairly maintained as indicated by gravimetric moisture content (Figure S3). Replenishing with the Hoagland solution is not typical in the agricultural field as field sites are well buffered for shortterm use for almost all nutrients. However, here it was needed to ensure that crops are not stressed due to lack of nutrients in the artificial substrate. Iron is usually not applied as fertilizer and is typically provided by soil-borne sources. The ample time gap given after 
each pore water collection was to maintain the semiarid conditions throughout the 60 days of the experiment.

\section{Soil and Plant Tissue Analyses}

Soil pH was measured twice a week by a 1:1 soil:water solution and measuring in a hand-held pH probe (Oakton PHTestrs 30) (Figure S2). Moisture content was measured at regular intervals and before pore water collection, by oven drying collected soil samples at $105{ }^{\circ} \mathrm{C}$ for $24 \mathrm{~h}$. Soil ORP (Oakton ORPTestr 50) was measured biweekly at a $5 \mathrm{~cm}$ depth, which utilized $\mathrm{Ag} / \mathrm{AgCl}, \mathrm{KCl}$ (saturated) as the reference electrode, and values were converted to a standard hydrogen electrode using the Nernst equation and reported at $E_{\mathrm{h}}(\mathrm{V})$. Soil samples from each pot were collected at the beginning and end of the experiment for trace metal analysis.

Postexperiment soil which had roots intertwined were collected as root zone soil sample. Arsenic and uranium was quantified by microwave digestion of the air-dried soil samples..$^{39,40} \mathrm{DCB}$ extraction was carried out for quantifying extractable iron in the soil. ${ }^{37}$ Briefly, 79.4 $\mathrm{g}$ of trisodium citrate and $9.24 \mathrm{~g}$ of sodium bicarbonate was dissolved in $1 \mathrm{~L}$ of reagent grade water, and $\mathrm{pH}$ of the final buffer solution was 7.3. In a 50-mL falcon tube, $3 \mathrm{~g}$ of a 24 -h air-dried soil sample was taken, and $45 \mathrm{~mL}$ of the buffer solution was added. The soil mixture was agitated in a hot water bath kept at $75{ }^{\circ} \mathrm{C}$ for $15 \mathrm{~min}$. After 15 min, $1 \mathrm{~g}$ of sodium dithionite was added and again kept in the hot water bath for $10 \mathrm{~min}$. After $10 \mathrm{~min}$, another $1 \mathrm{~g}$ of dithionite was added very slowly and agitated in the water bath for another $15 \mathrm{~min}$. Finally it was cooled down and centrifuged, and the extraction was collected. The extractions were acidified with trace certified $\mathrm{HCl}$ before analysis. The extractions were analyzed in inductively coupled plasma mass spectroscopy (Thermo Dionex IC 5000+ iCAP RQ ICP MS) for iron after 100-fold dilution using matrix match standards. Air-dried soil samples were ground to a fine powder and digested with hot nitric acid, and the digestates were subject to elemental analysis with ICP-MS. Soil CRMs were run to confirm the extraction and analysis method. X-ray photoelectron spectroscopy (XPS) (Thermo Scientific K-alpha + XPS, under $\mathrm{Al} \mathrm{K} \mathrm{X}_{\alpha}$-ray $\left(h v=1486.6 \mathrm{eV}, 10^{-9} \mathrm{mbar}\right)$ was utilized to 
confirm the iron oxidation state in the pre- and postexperiment soil samples. Postexperiment root zone soil samples were degassed in a vacuum desiccator before analysis in XPS. Plant tissues were cleaned and dried in an oven $\left(65^{\circ} \mathrm{C}\right)$ until constant weight to record the dry biomass, dried plant tissues (roots and shoots combined) were ground to a fine powder, and hot nitric acid digestion was carried out for elemental analysis with ICP-MS. ${ }^{\circ}$

\section{Pore Water Analyses}

Pore water samples were collected within 30 min after application of artificial irrigation water, filtered using a $0.45 \mu \mathrm{m}$ syringe filter, and subsampled. Given the size range of the added ferrihydrite ${ }^{17}$ and organic-iron complexes ${ }^{41}$ formed in the rhizosphere, the chance of introducing colloidal iron in the collected pore water sample at 0.45 $\mu \mathrm{m}$ is high but is considered to be a dissolved iron phase..$^{41}$ Collected pore water samples were analyzed in situ for reduced iron (Fe(II)) by the 1,10-phenanthroline method spectrophotometrically (Vernier Spectrophotometer, USA) at $510 \mathrm{~nm} \cdot{ }^{42-44} \mathrm{~A}$ part of the sample was acidified with trace-certified hydrochloric acid for arsenic, uranium and total iron quantification in ICP-MS and major cations analysis in atomic absorption spectroscopy (PerkinElmer AAnalyst 400 Spectrophotometer). A part of the sample was acidified with sulfuric acid for colorimetric (Seal AQ2 Autoanalyzer) analyses of nitrate and ammonia. Unpreserved pore water samples were used for DOC measurement by the persulfate oxidation method (Ol Model 1010 Carbon Analyzer), for major anion analysis in ion chromatography (Dionex ICS-90 Ion Chromatograph), and alkalinity measurement by the titrimetric method. Pore water samples concentration of arsenic and uranium reported here has been deducted with the concentration present in artificial irrigation water, which was $\sim 5.5 \pm 0.7 \mu \mathrm{g} / \mathrm{L}$ and $3.4 \pm 0.2 \mu \mathrm{g} / \mathrm{L}$ for arsenic and uranium, respectively. These concentrations are generally found in the groundwater of Nebraska, used for irrigation. Iron mass balance was carried out by measuring the mass of iron in pore water for $1 \mathrm{~h}$, total $\mathrm{Fh}-\mathrm{Fe}$, total acid digested iron, and iron uptake by crops. 


\section{Statistical Analyses}

Statistical analysis of collected data were carried out in Origin Pro 2019b software. Data were tested for normal distribution and homogeneity of variance. Pearson correlation coefficients were computed, and one-way ANOVA analyses were performed to statistically analyze the data for correlations and significant effects of the factors soil mixture (high Fh, low Fh) and crop type (corn, soybean) on selected parameters.

\section{Chemical Equilibrium Modeling}

The speciation model presented in this work was carried out by adopting the USGS chemical speciation program PHREEQC (version 3) ${ }^{45}$ (available from https://www.usgs.gov/software/phreeqc-version-3 coupled). With PHREEQC, species and reactions, as well as equilibrium constants, are all defined in a database file. The limitation of other databases (e.g., minteq dat, phreeqc.dat) is there is an inconsistency in the number of elements used in the databases. Thus, the database wateq4f.dat, derived from WATEQ $4 \mathrm{~F}^{46}{ }^{4}$ is adopted in this model to calculate the different species of the elements analyzed which includes uranium, arsenic, and iron. The model utilizes the nitrate/ammonium couple for calculation of redox-sensitive, which predicted equilibrium concentration of reduced iron in the pore water. ${ }^{47}$ The model-predicted values were then matched with experimental results. Model inputs include temperature, $\mathrm{pH}$, alkalinity, anions, cations, ammonia, and concentration of arsenic, iron, and uranium as obtained from ICP-MS measurements for each pore water sample. ${ }^{47}$

\section{Results and discussion}

\section{Ferrihydrite Transformation}

In the greenhouse, the irrigation schedule was kept similar to a typical crop production setup in the US Midwest. ${ }^{48,49}$ Artificial soil mixtures ${ }^{36}$ were prepared with known mineral and elemental composition and used as growth medium for evaluating the effect of Fh transformation 
on mobilization and bioavailability of contaminants. The artificial soil contained 2-line Fh as the only source of mineral iron in two concentrations (soil\# 1: $\sim 0.10 \% \mathrm{w} / \mathrm{w}$ and soil\# 2: 0.15\% w/w), which are within the range of natural soil, as observed in field samples from central and western Nebraska. The Fh mixed into the artificial soil was synthesized in the laboratory and contained controlled amounts of coprecipitated arsenic and uranium. ${ }^{33}$ The $E_{\mathrm{h}}$ ORP of bulk soil varied from 0.401 to $0.452 \mathrm{~V}$, and $\mathrm{pH}$ was $6.5-7.5$ (Figure S2), indicative of predominantly suboxic to marginally oxic conditions. ${ }^{\circ}$ Development of anoxic microsites and iron reduction within the rhizosphere can take time, and samples were collected after sufficient time, which was given for the crops to grow. Pore water was collected from pots on the 2oth, 40th, and 6oth day of the experiment and analyzed for $\mathrm{Fe}^{2+}$, total dissolved iron, arsenic, uranium, and other elements. After 60 days, the crops were harvested and analyzed for their chemical composition.

Irrespective of crop type and soil mixture, $\mathrm{Fe}^{2+}$ was observed in the pore water (Figure 1b,c). Pore water collected after a substantial dry period ( $\sim 13.6 \pm 0.9 \%$ water content from day 1 to 20 , no watering between day 22 to 39 and day 42 to 59 (Figure S3)) contained measurable levels of reduced iron. Cumulative $\mathrm{Fe}^{2+}$ concentration (sum of the average $(n=6)$ concentrations measured at Day 20, 40, and 60) was $750 \mu \mathrm{g} \mathrm{L} \mathrm{L}^{-1}$ (soil \#1) and $885 \mu \mathrm{g} \mathrm{L} \mathrm{L}^{-1}$ (soil \#2) for soybean and $414 \mu \mathrm{g} \mathrm{L}^{-1}$ (soil \#1) and $760 \mu \mathrm{g} \mathrm{L}^{-1}$ (soil \#2) for corn. Pore water from soybean had significantly more $\mathrm{Fe}^{2+}$, which is expected, as iron uptake in soybean is via reduction pathway. ${ }^{51,52}$ The largest amount of $\mathrm{Fe}^{2+}$ was detected in the first sampling at day 20 for both crops, which decreased midterm (day 40) and increased again at day 60 of the experiment suggesting iron redox cycles within the growing period. Cumulative arsenic concentrations in soil pore water were $72 \mu \mathrm{g} \mathrm{L}^{-1}$ (soil \#1) and $139 \mu \mathrm{g} \mathrm{L} \mathrm{L}^{-1}$ (soil \#2) for soybean and 65.4 $\mu \mathrm{g} \mathrm{L}^{-1}$ (soil \#1) and $105 \mu \mathrm{g}$ $\mathrm{L}^{-1}$ (soil \#2) for corn. For the respective uranium concentrations, we detected 19.2 $\mu \mathrm{g} \mathrm{L}^{-1}$ (soil \#1) and $23.2 \mu \mathrm{g} \mathrm{L}^{-1}$ (soil \#2) for soybean and $15.8 \mu \mathrm{g} \mathrm{L}^{-1}$ (soil \#1) and $18.2 \mu \mathrm{g} \mathrm{L} \mathrm{L}^{-1}$ (soil \#2) for corn. The $\mathrm{Fe}^{2+}$ concentrations in pore water correlated significantly with concentrations of $\operatorname{arsenic}(r=0.70, p<0.01)$ and uranium $(r=0.65, p<0.01)$. We take this as evidence for iron reduction in the soil pointing toward 2-line Fh reductive dissolution leading to elevated concentrations of arsenic 
and uranium in the pore water in both soils (Figure 1b,c). The amount of total iron in the pore water correlated well with the amount of arsenic and uranium in the pore water, and in some cases, iron was almost entirely in reduced form. Soluble uranium has been observed to increase with iron reduction under comparable $\mathrm{pH}$ in anoxic microcosm. ${ }^{53}$ However, compared to arsenic, lower uranium concentration in the pore water in the present study may be due to the possible conversion of highly soluble U(VI) to sparingly soluble U(IV), which may be associated either with particulate organic matter, including biomass, or form sparingly soluble $\mathrm{UO}_{2}$ phases. ${ }^{54,55}$ Thus, uranium may not be available in high concentration in the mobilized form for crop uptake.

Chemical equilibrium modeling of the pore water was carried out using PHREEQC 45 to understand different geochemical processes occurring in the soil and predict equilibrium forms of iron ions and minerals in pore water. $\mathrm{Fe}^{2+}$ concentrations predicated by the model were in good agreement with experimentally detected values (Table S1). The model also indicated that the saturation index of Fh in the pore water increased as the experiment progressed. The increase from a negative to a positive value of saturation index (Table S1) suggested that the pore water solution became supersaturated with suspended Fh mineral at the later stage of the experiment, which may indicate potentially new Fh was formed between irrigations.

Pore water concentrations of phosphate (Figure $\mathrm{S}_{4}$ ), which is known to bind strongly with iron oxides, ${ }^{22}$ correlated strongly with $\mathrm{Fe}^{2+}(r=0.82, p<0.01)$. DOC increased throughout the experiment ( 7.8 to $35.8 \mathrm{mg} \mathrm{C}^{-1}$ ) (Figure $\mathrm{S} 4$ ). The DOC concentrations in pore water correlated significantly $(r=0.79, p<0.01)$ with total iron. The data suggest that dissolvable, low molecular weight carbon moieties and phosphate mobility seems to be coupled to iron redox based processes at anoxic microsites within unsaturated bulk soil. These findings correlate well with a recent study by Warrinnier et al. ${ }^{56}$ where anaerobic microsites, sparked from the presence of dissolved organic carbon, in well-drained soil were found to mobilize phosphate.

\section{Changes on the Iron Oxidation State in Soil}

Similar to the pore water, changes in the oxidation state of iron were observed in both soils. Pre- and postexperiment samples from both 

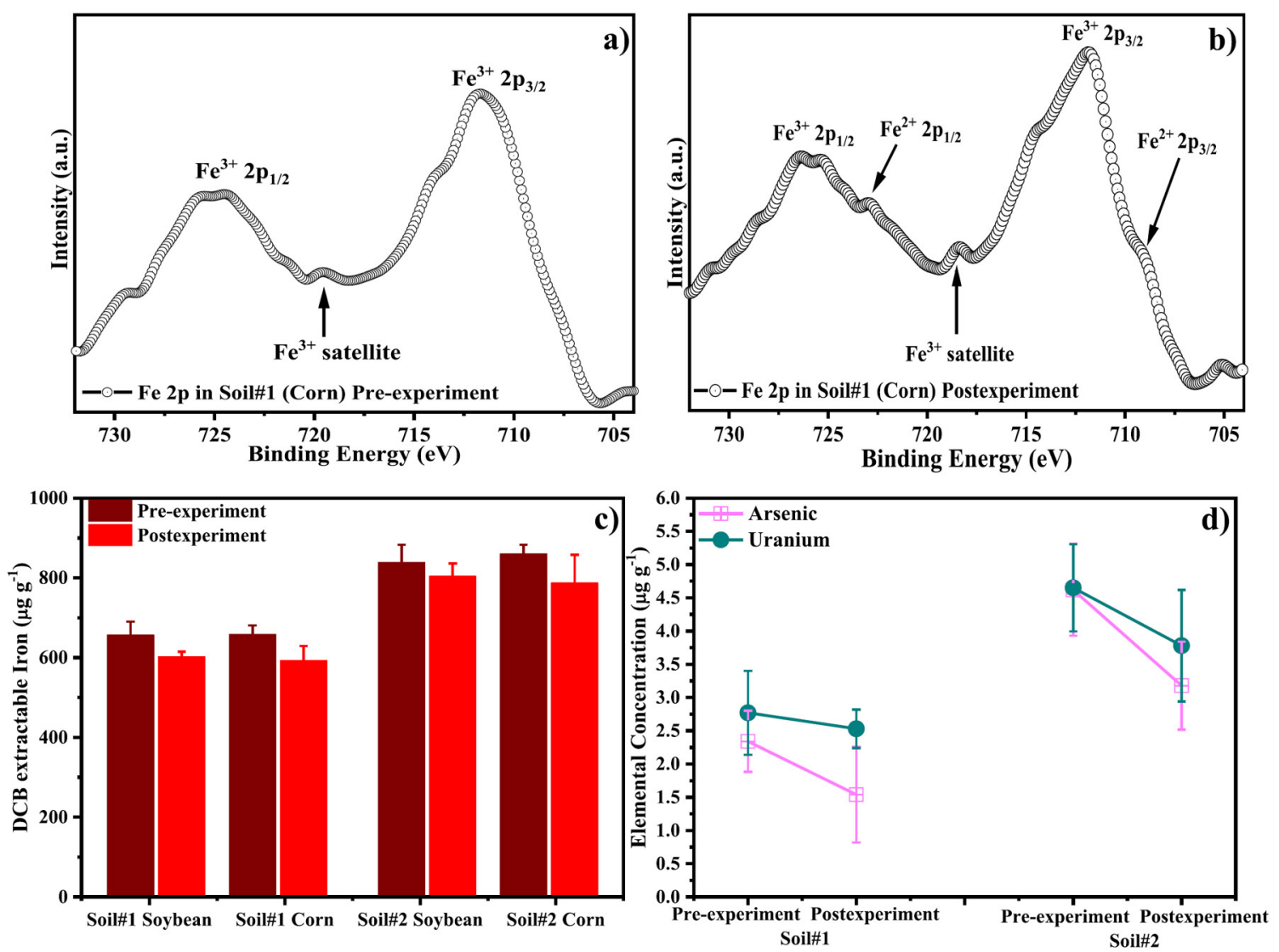

Figure 2. a) Oxidation states of iron in the initial sample (Soil\#1, corn), b) oxidation states of iron in the postexperiment sample (Soil\#1, corn) observed with XPS, c) dithionite extractable iron for both soils and crops, and d) uranium and arsenic concentrations in both soils (average of all crops and error bar is standard deviation). For Soil\#1, which had less amount of Fh and is shown here, two peaks humps were observed in the postsoil sample indicating the presence of two different forms of $\mathrm{Fe}^{2+}$ and $\mathrm{Fe}^{3+} .{ }^{57,58}$ Similarly, the amount of extractable iron is also less in the postexperiment sample compared to the presample. Trace contaminant concentration has also been reduced in the postexperiment samples for both soils.

soils were characterized with XPS. Figure 2a,b shows pre- and postexperiment soil samples from corn pot of soil\#1. The postexperiment sample contained $\mathrm{Fe}^{2+}\left(\sim 709.0 \mathrm{eV} \mathrm{Fe}{ }^{2+} 2 \mathrm{p}_{3 / 2}, \sim 722.5 \mathrm{eV} \mathrm{Fe}{ }^{2+}\right.$ $\left.2 \mathrm{p}_{3 / 2}\right)$ and $\mathrm{Fe}^{3+}\left(\sim 711.6 \mathrm{eV} \mathrm{Fe}{ }^{3+} 2 \mathrm{p}_{3 / 2}, \sim 725.3 \mathrm{eV} \mathrm{Fe}^{3+} 2 \mathrm{p}_{3 / 2}\right)$, whereas the initial soil contained only $\mathrm{Fe}^{3+}\left(\sim 711.4 \mathrm{eV} \mathrm{Fe}^{3+} 2 \mathrm{p}_{3 / 2}, \sim 724.6 \mathrm{eV}\right.$ $\mathrm{Fe}^{3+} 2 \mathrm{p}_{3 / 2}$ ), with a satellite peak at $\sim 719.5 \mathrm{eV}$ (Figure 2a,b)..$^{57,58}$ The presence of reduced iron in soil at the end of the experiment is from 
iron originating from the 2-line Fh added to the artificial soil. These results show the occurrence of iron reduction under partially saturated soils, which is potentially coupled to the iron requirement of crops. We assume these processes to be concentrated in the anoxic microsites at the root zone-soil-pore water interface, and that reduction of iron will lead to the release of iron oxide-bound contaminants and nutrients near the root zone.

Observation of reduced iron under these soil conditions is unique and has implications also for nitrogen and carbon cycles near the root zone as these are redox-sensitive. Variations in nitrogen species (nitrate and ammonium) were also monitored in the soil samples and found to correlate strongly with Fh concentration present in the soil $(r=0.95, p<0.01)$. Iron chemistry in nonflooded soil is presumed to occur primarily in oxidized mineral forms. ${ }^{59}$ However, our study confirms that reactive iron minerals, such as Fh, can undergo transformation via the reductive dissolution pathway playing an important role in geochemical cycles under these soil conditions.

The amount of DCB extractable iron was reduced in postexperiment soil samples compared to soil concentrations at the beginning (Figure 2c). A mass balance of iron suggests that it either leached out of the system or was taken up by crops, and a small percentage of DCB extractable iron ( 7.6 $\pm 4.2 \%)$ was unaccounted for, which may have converted to other mineral forms, ${ }^{60}$ which are not extractable by DCB (Table S3). The amount of arsenic and uranium decreased in the postexperiment soil sample (Figure 2d). Both arsenic $(r=0.81, p<0.01)$ and uranium $(r=0.68, p<0.01)$ postexperiment soil concentration correlated significantly with the Fh content. The decrease in contaminants was higher in soil\#2 compared to soil\# 1 . The release of more arsenic and uranium in soil\#2 is comparable with the decline in soil Fh and elevated uptake of contaminant by crops in soil\#2. This was expected because plants take up more iron ${ }^{61}$ whenever available, and in our experiment, soil\#2 contained more iron than soil\#1. Fh transformation processes in these soils seem to control the mobility of the trace contaminants under nonflooded irrigation conditions. 


\section{Implication on Crop Uptake Due to the Mobilization of Contaminants}

The unsaturated conditions maintained throughout the experiment created water stress for the crops in the later part of the experiment, between the second and final collections. There was no visible symp-

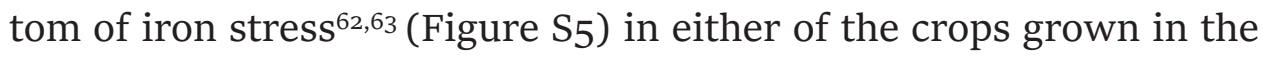
soil mixtures. Iron present as ferrihydrite most likely provides enough plant-available iron as compared to natural soils where other less reactive forms of iron minerals are present. The mobilization of trace elements at the root zone has direct impact on the plant uptake of these contaminants. We observe that plants take up both contaminants irrespective of the soil (Figure 4). Uptake of arsenic was highest, which is not surprising as arsenic was more bioavailable in the pore water and may be more driven by Fh reduction. Immature plants had no grains due to the short study period of 60 days, so Figure 4 shows arsenic and uranium uptake in the whole crop. In both crops, there was significantly higher uptake in soil\# 2 compared to soil\#1. Soybean took up more trace contaminants than corn because iron uptake in soybean occurs via extracellular reduction ${ }^{51,52}$ and is more crucial for soybean growth. The enhanced rate of iron uptake in soybean, promoted iron reduction releasing arsenic and uranium, which were subsequently taken up by the crops. Higher uptake of uranium in soybean shoots and roots was observed in comparison to corn in a previous study, and uptake amount increased in both crops as the concentration of uranium increased in the growing media. ${ }^{64}$ In that study, uranium uptake was highest in soybean shoots $(9.9 \mu \mathrm{g} / \mathrm{g})$ followed by corn shoots $(8.5 \mu \mathrm{g} / \mathrm{g})$, followed by roots of soybean $(1.8 \mu \mathrm{g} / \mathrm{g})$ and corn $(1.6 \mu \mathrm{g} / \mathrm{g})$, and the concentration of growing media was $15.3 \mathrm{mg}$ $\mathrm{kg}^{-1} \cdot{ }^{64}$ Arsenic uptake in soybean matches well with a previous study at a similar concentration range of bioavailable arsenic in soil. ${ }^{65}$ The concentration of arsenic in corn was on the higher side than what is generally observed but within the range of reported uptake amounts. ${ }^{66}$ The bioconcentration factor (BCF) in soybean for arsenic was found to be 1.7 and 1.3 in soil\# 1 and soil\#2, respectively, and for uranium it was found to be 0.3 and 0.7 for soil\#1 and \#2, respectively. The BCF in corn for arsenic was 1.7 and 1.2 in soil\#1 and \#2, and for uranium it was 0.3 and 0.3 in soil\# 1 and \#2, respectively. 


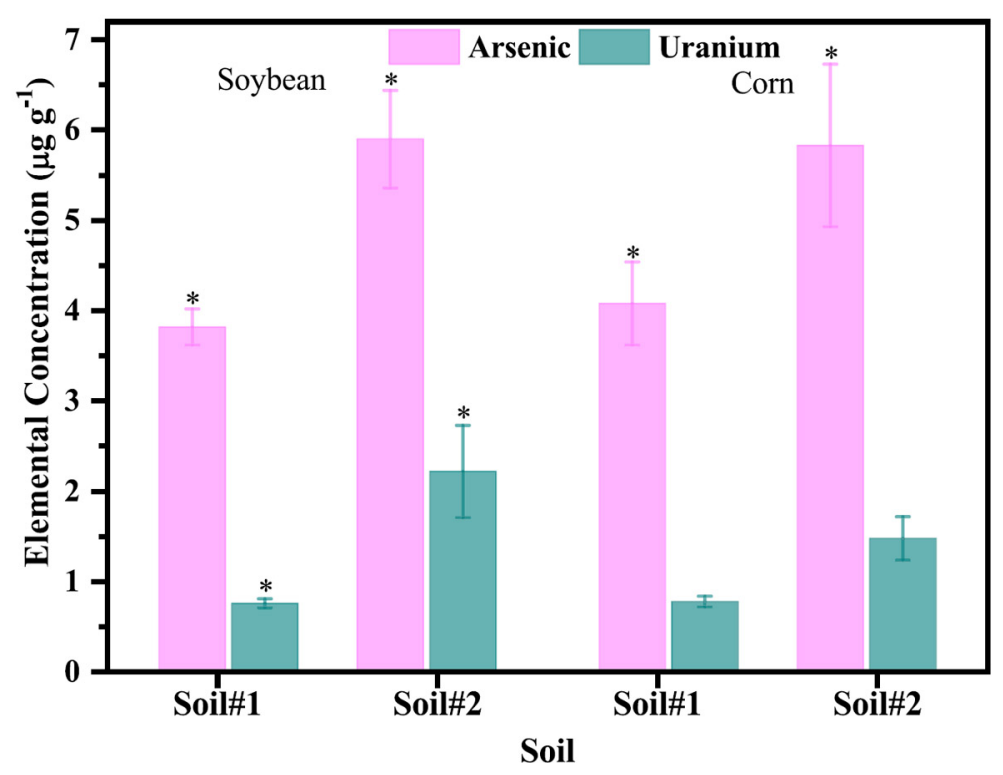

Figure 3. Uptake of arsenic and uranium by the entire crop (soybean and corn) for both soils. The asterisk $\left(^{*}\right)$ shows significantly different uptake concentrations in the same crop type under two different levels of Fh in the starting soil.

The initial concentration of Fh in soil correlated strongly and significantly with arsenic $(r=0.81, p<0.01)$ and uranium $(r=0.98$, $p<0.01)$ uptake in soybean. A significantly strong correlation was observed for uranium $(r=0.97, p<0.01)$ uptake in corn. Plant iron concentration showed significant correlation with plant arsenic $(r$ $=0.88, p<0.01)$ and uranium $(r=0.97, p<0.01)$ concentration for soybean, but no such relation was found among corn crops. This may be due to the difference in the uptake mechanism of iron for both crop types. Soil\#1 had less arsenic and uranium to start with and showed less plant available to arsenic and uranium, which is evident from the lower amount that has been taken up by both crops compared to soil\#2 (Figure 3). Arsenic seems to be more bioavailable compared to uranium and more affected by Fh reductive dissolution $^{67}$ and shows a significantly $(p<0.05)$ different uptake amount between soil\#1 and soil\# 2 for both crop types, and uranium concentration in soybean showed a significant $(p<0.05)$ difference between soil\#1 and soil\#2. Higher $\mathrm{Fe}^{2+}$ in the pore water correlates with higher uptake by the crop regardless of the soil. However, corn 
plants can take up $\mathrm{Fe}^{3+}$ directly by solubilizing iron, ${ }^{68}$ even though reduced iron was observed in this study. Crop demand for iron can explain reduced iron in the unsaturated rhizosphere of legumes such as soybean, as iron reduction is the main source of this micronutrient for legumes. ${ }^{51,52}$ However, for grasses such as corn, the main uptake mechanism is chelation, not reduction, ${ }^{51,52}$ which makes the latter unlikely to serve as the main source of reduced iron. This indicates that localized redox sites existing at the root zone-soil-pore water interface contribute to reductive iron mobilization irrespective of iron plant uptake mechanism (Figure 4). Anoxic microsites are generated due to the higher water potential at zones within the soil, while the soil as a whole remains unsaturated.

Anoxic microsites can harbor microbes, and microbial processes occurring within these microsites may be responsible for the presence of reduced iron in the pore water. ${ }^{27}$ Artificial soils, even under strict sterile conditions, are known to support microbial activity. ${ }^{36,69} \mathrm{Mi}$ crobes, which are required for rhizosphere processes, can be present in the root zone-soil-pore water interface ${ }^{70-72}$ and presumably utilize iron reduction for electron shuttling, ${ }^{21}$ which can possibly explain the presence of $\mathrm{Fe}^{2+}$ in corn. The increase in arsenic mobilization has been linked to iron-reducing bacteria in the rice rhizosphere under flooded conditions. ${ }^{73}$ Similar microbial processes can occur under transiently saturated conditions during a short irrigation period within the anoxic microsites. ${ }^{74,75}$ The reduction of iron in the porous unsaturated, semiarid bulk soil due to the presence of anoxic microsites is the primary outcome of the present study. The release of contaminants such as arsenic from the reductive dissolution of ferrihydrite is a consequence of the presence of anoxic microsites in the unsaturated soil. Our results highlight that the dynamics of reactive iron minerals can control the availability of nutrients and trace elements in unsaturated soil. For these processes, contributions of anoxic microsites in partially saturated irrigated soils need to be considered. The presence of anoxic microsites in the root zone-soil-pore water interface can control important redox-sensitive reactions at the rhizosphere. Iron mineral transformation at these interfaces is one of the key biogeochemical reactions of the rhizosphere, mainly because of iron requirements of the crops and the ability of iron oxides to control the mobility of trace element contaminants. 


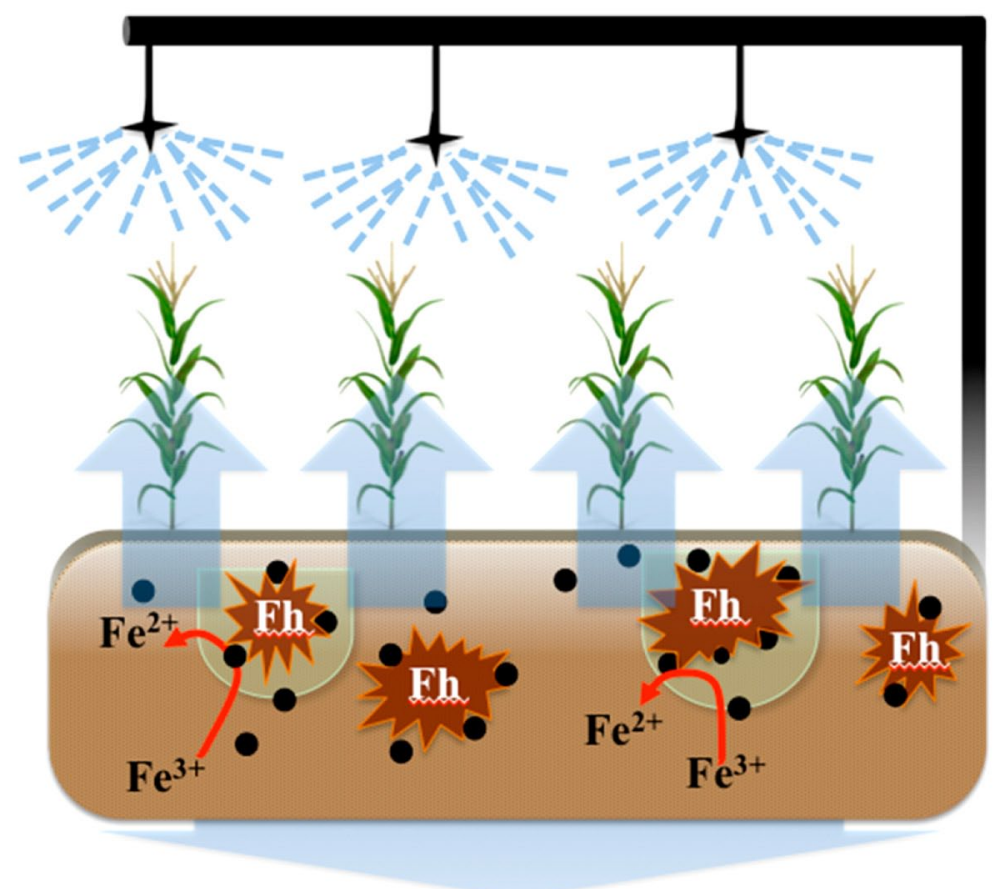

Figure 4. Conceptual model of ferrihydrite (Fh) reduction in semiarid surface soil in root zone-soil-pore water redox hotspots. In partially saturated irrigated conditions, soil is generally dry (arid to semiarid). Crops grown in these conditions need iron for proper growth, and the roots take up iron either by chelation or reduction ferrous iron. These processes for iron uptake require anoxic microsites near the root zone, which provide conditions for reductive dissolution of iron minerals such as Fh. Fh is known to chemisorb a plethora of trace elements (black circles in the figure) that are mobilized due to this transformation at the root zone, rendering them available for crop uptake or prone to subsequent leaching into the unsaturated zone below.

While the concentration of Fh used in this experiment was comparable to field soils, nevertheless, downstream experiments under actual field conditions are needed to validate the results of this study. These results, however, provide the framework for future field studies examining the role of $\mathrm{Fh}$ in trace element contaminant mobilization and bioavailability under unsaturated conditions. Iron reduction in soils under sprinkler or subsurface drip irrigation can have major implications for iron and trace element mobilization and for the biogeochemical cycles of carbon and phosphorus in the root zone. These processes need to be understood at a mechanistic detail because nutrients and contaminants mobilized in the root zone can be taken up 
by crops or infiltrate the groundwater. Finally, the redox-driven iron pathway in unsaturated soils under semiarid to arid conditions appears to be crucial for water and food security.

Declaration The authors declare no competing financial interest.

Acknowledgments This work was partially supported by the Nebraska Agricultural Experiment Station with funding from the Hatch Multistate Research (Accession Number 1011588) through the USDA National Institute of Food and Agriculture. The research was performed in part in the Nebraska Nanoscale Facility: National Nanotechnology Coordinated Infrastructure and the Nebraska Center for Materials and Nanoscience, which are supported by the National Science Foundation under Award ECCS: 2025298 and the Nebraska Research Initiative. A.M. thanks NET for salary support.

\section{Supporting Information}

The Supporting Information is available free of charge at https://pubs.acs.org/ doi/10.1021/acs.est.0c02670.

Supporting Information is also presented following the References.

Figure S1, powder X-ray diffraction pattern of arsenic and uranium coprecipitated 2-line ferrihydrite

Figure $\mathrm{S} 2$, temporal soil $\mathrm{pH}$ variation

Figure $\mathrm{S} 3$, temporal gravimetric moisture content variation

Figure $\mathrm{S} 4$, temporal variation of nitrate-N, ammonia-N, dissolved organic carbon, potassium, and orthophosphate concentration in pore water samples collected from soil\#1 and soil\#2 under two crop types

Figure S5, images of crops

Table S1, compares reduced iron concentration observed and predicted from chemical equilibrium model

Table S2, saturation indices of ferrihydrite in pore water as predicted by chemical equilibrium model; and Table S3, iron mass balance for different replicates

\section{References}

1) Punshon, T.; Jackson, B. P.; Meharg, A. A.; Warczack, T.; Scheckel, K.; Guerinot, M. L. Understanding Arsenic Dynamics in Agronomic Systems to Predict and Prevent Uptake by Crop Plants. Sci. Total Environ. 2017, 581-582, 209-220.

2) Hakonson-Hayes, A. C.; Fresquez, P. R.; Whicker, F. W. Assessing Potential Risks from Exposure to Natural Uranium in Well Water. J. Environ. Radioact. 2002, 59 (1), 29-40. 
3) Smith, A. H.; Lingas, E. O.; Rahman, M. Contamination of Drinking-Water by Arsenic in Bangladesh: A Public Health Emergency. Bull. World Health Organ. 2000, 78 (9), 1093-1103.

4) Bjørklund, G.; Albert Christophersen, O.; Chirumbolo, S.; Selinus, O.; Aaseth, J. Recent Aspects of Uranium Toxicology in Medical Geology. Environ. Res. 2017, 156 (April), 526-533.

5) Chen, X. P.; Zhu, Y. G.; Hong, M. N.; Kappler, A.; Xu, Y. X. Effects of Different Forms of Nitrogen Fertilizers on Arsenic Uptake by Rice Plants. Environ. Toxicol. Chem. 2008, 27 (4), 881-887.

6) Wang, X.; Liu, T.; Li, F.; Li, B.; Liu, C. Effects of Simultaneous Application of Ferrous Iron and Nitrate on Arsenic Accumulation in Rice Grown in Contaminated Paddy Soil. ACS Earth Sp. Chem. 2018, 2 (2), 103-111.

7) Melton, E. D.; Swanner, E. D.; Behrens, S.; Schmidt, C.; Kappler, A. The Interplay of Microbially Mediated and Abiotic Reactions in the Biogeochemical Fe Cycle. Nat. Rev. Microbiol. 2014, 12, 797-808.

8) Sparks, D. L. Inorganic Soil Components. In Environmental Soil Chemistry; Elsevier: 2003; pp 43-73, https://doi.org/10.1016/ b978-012656446-4/50002-5

9) Li, N.; Wang, J.; Song, W. Y. Arsenic Uptake and Translocation in Plants. Plant Cell Physiol. 2016, 57 (1), 4-13.

10) Brown, J. C. Mechanism of Iron Uptake by Plants. Plant, Cell Environ. 1978, 1 (4), 249-257.

11) Olsen, R. A.; Miller, R. O. Absorption of Ferric Iron by Plants. J. Plant Nutr. 1986, 9, 751-757.

12) Thompson, A.; Chadwick, O. A.; Boman, S.; Chorover, J. Colloid Mobilization during Soil Iron Redox Oscillations. Environ. Sci. Technol. 2006, 40 (18), 5743-5749.

13) Dyanand, S.; Sinha, M. K. Labile Pool and Selective Distribution of Iron in Calcareous and Sodic Soils. Plant Soil 1985, 88 (1), 11-21.

14) Raiswell, R.; Vu, H. P.; Brinza, L.; Benning, L. G. The Determination of Labile Fe in Ferrihydrite by Ascorbic Acid Extraction: Methodology, Dissolution Kinetics and Loss of Solubility with Age and de-Watering. Chem. Geol. 2010, $278(1-2), 70-79$.

15) McKeague, J. A.; Schuppli, P. A. An Assessment of EDTA as an Extractant of Organic-Complexed and Amorphous Forms of Fe and Al in Soils. Geoderma 1985, 35 (2), 109-118.

16) Geiger, S. C.; Loeppert, R. H. Correlation of Dtpa Extractable Fe with Indigenous Properties of Selected Calcareous Soils. J. Plant Nutr. 1986, 9 (3-7), 229-240.

17) Michel, F. M.; Ehm, L.; Antao, S. M.; Lee, P. L.; Chupas, P. J.; Liu, G.; Strongin, D. R.; Schoonen, M. A. A.; Phillips, B. L.; Parise, J. B. The Structure of Ferrihydrite, a Nanocrystalline Material. Science (Washington, DC, U. S.) 2007, 316 (5832), 1726-1729. 
18) Vodyanitskii, Y. N.; Shoba, S. A. Ferrihydrite in Soils. Eurasian Soil Sci. 2016, 49 (7), 796-806.

19) Chen, C.; Meile, C.; Wilmoth, J.; Barcellos, D.; Thompson, A. Influence of $\mathrm{PO} 2$ on Iron Redox Cycling and Anaerobic Organic Carbon Mineralization in a Humid Tropical Forest Soil. Environ. Sci. Technol. 2018, 52 (14), 7709-7719.

20) Dieter, C. A.; Maupin, M. A.; Caldwell, R. R.; Harris, M. A.; Ivahnenko, T. I.; Lovelace, J. K.; Barber, N. L.; Linsey, K.. Estimated Use of Water in the United States in 2015: U.S. Geological Survey Circular 1441; 2018; https://doi. org/10.3133/cir1441

21) Mejia, J.; Roden, E. E.; Ginder-Vogel, M. Influence of Oxygen and Nitrate on Fe (Hydr)Oxide Mineral Transformation and Soil Microbial Communities during Redox Cycling. Environ. Sci. Technol. 2016, 50 (7), 3580-3588.

22) Ippolito, J. A.; Bjorneberg, D. L.; Blecker, S. W.; Massey, M. S. Mechanisms Responsible for Soil Phosphorus Availability Differences between Sprinkler and Furrow Irrigation. J. Environ. Qual. 2019, 48, 1370.

23) Colombo, C.; Palumbo, G.; He, J. Z.; Pinton, R.; Cesco, S. Review on Iron Availability in Soil: Interaction of Fe Minerals, Plants, and Microbes. J. Soils Sediments 2014, 14 (3), 538-548.

24) Keiluweit, M.; Wanzek, T.; Kleber, M.; Nico, P.; Fendorf, S. Anaerobic Microsites Have an Unaccounted Role in Soil Carbon Stabilization. Nat. Commun. 2017, https://doi.org/10.1038/s41467-017-01406-6

25) Yang, W. H.; Weber, K. A.; Silver, W. L. Nitrogen Loss from Soil through Anaerobic Ammonium Oxidation Coupled to Iron Reduction. Nat. Geosci. 2012, 5, 538.

26) Fendorf, S.; Keiluweit, M.; Schaefer, M.; Masue-Slowey, Y.; Chadwick, O. Intimate and Complex Coupling of Carbon and Iron Cycles within Terrestrial Systems. In Abstracts of Papers, 255th ACS National Meeting \& Exposition, New Orleans, LA, United States, March 18-22, 2018; American Chemical Society: Washington, DC, 2018.

27) Keiluweit, M.; Gee, K.; Denney, A.; Fendorf, S. Anoxic Microsites in Upland Soils Dominantly Controlled by Clay Content. Soil Biol. Biochem. 2018, 118, $42-50$.

28) Hall, S. J.; Silver, W. L. Reducing Conditions, Reactive Metals, and Their Interactions Can Explain Spatial Patterns of Surface Soil Carbon in a Humid Tropical Forest. Biogeochemistry 2015, 125 (2), 149-165.

29) Keiluweit, M.; Nico, P. S.; Kleber, M.; Fendorf, S. Are Oxygen Limitations under Recognized Regulators of Organic Carbon Turnover in Upland Soils? Biogeochemistry 2016, 127 (2-3), 157- 171.

30) Jin, C. W.; Li, G. X.; Yu, X. H.; Zheng, S. J. Plant Fe Status Affects the Composition of Siderophore-Secreting Microbes in the Rhizosphere. Ann. Bot. 2010, 105 (5), 835-841.

31) Jin, C. W.; Ye, Y. Q.; Zheng, S. J. An Underground Tale: Contribution of Microbial Activity to Plant Iro. Ann. Bot. 2014, 113 (1), 7-18. 
32) Liu, X.; Fu, J. - W; Da Silva, E.; Shi, X. - X; Cao, Y.; Rathinasabapathi, B.; Chen, Y.; Ma, L. Q. Microbial Siderophores and Root Exudates Enhanced Goethite Dissolution and Fe/As Uptake by As-Hyperaccumulator Pteris Vittata. Environ. Pollut. 2017, 223, 230- 237.

33) Islam, S.; Ray, S.; Malakar, A. Method for Instantaneous 2-Line Ferrihydrite Synthesis Using Layered Hydroxide Pathway and Removal of Arsenic from Contaminated Water by in-Situ Application of Layered Hydroxide Materials. $201631036642,2016$.

34) Islam, S.; Das, S.; Mishra, G.; Das, B.; Malakar, A.; Carlomagno, I.; Meneghini, C.; de Giudici, G.; Gonçalves, L. P. L.; Sousa, J. P. S.; et al. Coagulating and Flocculating Ferrihydrite: Application of Zinc Acetate Salt. Environ. Sci. Water Res. Technol. 2020, 6, 2057.

35) Zhu, B.; Jia, Y.; Jin, Z.; Sun, B.; Luo, T.; Kong, L.; Liu, J. A Facile Precipitation Synthesis of Mesoporous 2-Line Ferrihydrite with Good Fluoride Removal Properties. RSC Adv. 2015, 5 (103), 84389- 84397.

36) Kaiser, M.; Ghezzehei, T. A.; Kleber, M.; Myrold, D. D.; Berhe, A. A. Influence of Calcium Carbonate and Charcoal Applications on Organic Matter Storage in Silt-Sized Aggregates Formed during a Microcosm Experiment. Soil Sci. Soc. Am. J. 2014, 78 (5), 1624.

37) Amaral, D. C.; Lopes, G.; Guilherme, L. R. G.; Seyfferth, A. L. A New Approach to Sampling Intact Fe Plaque Reveals Si-Induced Changes in Fe Mineral Composition and Shoot As in Rice. Environ. Sci. Technol. 2017, 51 (1), 38-45.

38) Hoagland, D. R.; Arnon, D. I. The Water-Culture Method for Growing Plants without Soil. Circular; California Agricultural Experiment Station: 1950; Vol. 347.

39) Link, D. D.; Walter, P. J.; Kingston, H. M. Development and Validation of the New EPA Microwave-Assisted Leach Method 3051A. Environ. Sci. Technol. 1998, 32 (22), 3628-3632.

40) United States Environmental Protection Agency (EPA). Method 3052: Microwave Assisted Acid Digestion of Siliceous and Organically Based Matrices; 1996.

41) Ritter, K.; Aiken, G. R.; Ranville, J. F.; Bauer, M.; Macalady, D. L. Evidence for the Aquatic Binding of Arsenate by Natural Organic Matter-Suspended Fe(III). Environ. Sci. Technol. 2006, 40 (17), 5380-5387.

42) Kaifer, A. E. Fundamentals of Analytical Chemistry Sixth Edition (Douglas A. Skoog, Donald M. West, and James F. Hollar). J. Chem. Educ. 1992, 69, A305.

43) Zhu, J.; Yang, X.; Fan, F.; Li, Y. Factors Affecting the Determination of Iron Species in the Presence of Ferric Iron. Appl. Water Sci. 2018, 8 (8), 228.

44) Tamura, H.; Goto, K.; Yotsuyanagi, T.; Nagayama, M. Spectrophotometric Determination of Iron(II) with 1,10-Phenanthroline in the Presence of Large Amounts of Iron(III). Talanta 1974, 21 (4), 314-318.

45) Parkhurst, D. L.; Appelo, C. A. J. PHREEQC (Version 3)-A Computer Program for Speciation, Batch-Reaction, One-Dimensional Transport, and Inverse Geochemical Calculations. Model. Technol. B 2013, 6, 497. 99-4259.

46) Ball, J. W.; Nordstrom, D. K. User's Manual for WATEQ4F, with Revised Thermodynamic Data Base and Text Cases for Calculating Speciation of Major, 
Trace, and Redox Elements in Natural Waters; Open-File Report 91-183; 1991; https://doi.org/10.3133/ofrg1183.

47) Nordstrom, D. K.; Plummer, L. N.; Wigley, T. M. L.; Wolery, T. J.; Ball, J. W.; Jenne, E. A.; Bassett, R. L.; Crerar, D. A.; Florence, T. M.; Fritz, B.; et al. A Comparison of Computerized Chemical Models for Equilibrium Calculations in Aqueous Systems. In Chemical Modeling in Aqueous Systems; Jene, E. A., Ed.; American Chemical Society: 1979; pp 857-892, https://doi.org/10.1021/ bk-1979-0093.cho38.

48) Irmak, S.; Haman, D. Z.; Bastug, R. Determination of Crop Water Stress Index for Irrigation Timing and Yield Estimation of Corn. Agron. J. 2000, 92, 1221.

49) Bowman, J. A.; Simmons, F. W.; Kimpel, B. C. Irrigation in Midwest: Lessons from Illinois. J. Irrig. Drain. Eng. 1991, 117, 700.

50) Borch, T.; Kretzschmar, R.; Kappler, A.; Cappellen, P.; Van; Ginder-Vogel, M.; Voegelin, A.; Campbell, K. Biogeochemical Redox Processes and Their Impact on Contaminant Dynamics. Environ. Sci. Technol. 2010, 44 (1), 15-23.

51) Morrissey, J.; Guerinot, M. L. Iron Uptake and Transport in Plants: The Good, the Bad, and the Ionome. Chem. Rev. 2009, 109 (10), 4553-4567.

52) Bai, G.; Jenkins, S.; Yuan, W.; Graef, G. L.; Ge, Y. Field-Based Scoring of Soybean Iron Deficiency Chlorosis Using RGB Imaging and Statistical Learning. Front. Plant Sci. 2018, 9, 1002.

53) Burkhardt, E.-M.; Akob, D. M.; Bischoff, S.; Sitte, J.; Kostka, J. E.; Banerjee, D.; Scheinost, A. C.; Küsel, K. Impact of Biostimulated Redox Processes on Metal Dynamics in an Iron-Rich Creek Soil of a Former Uranium Mining Area. Environ. Sci. Technol. 2010, 44 (1), 177-183.

54) Du, X.; Boonchayaanant, B.; Wu, W.-M.; Fendorf, S.; Bargar, J.; Criddle, C. S. Reduction of Uranium(VI) by Soluble Iron(II) Conforms with Thermodynamic Predictions. Environ. Sci. Technol. 2011, 45 (11), 4718-4725.

55) Bone, S. E.; Cliff, J.; Weaver, K. L.; Takacs, C. J.; Roycroft, S.; Fendorf, S.; Bargar, J. R. Complexation by Organic Matter Controls Uranium Mobility in Anoxic Sediments. Environ. Sci. Technol. 2020, 54, 1493.

56) Warrinnier, R.; Bossuyt, S.; Resseguier, C.; Cambier, P.; Houot, S.; Gustafsson, J. P.; Diels, J.; Smolders, E. Anaerobic Respiration in the Unsaturated Zone of Agricultural Soil Mobilizes Phosphorus and Manganese. Environ. Sci. Technol. 2020, 54 (8), 4922-4931.

57) Mallet, M.; Barthélémy, K.; Ruby, C.; Renard, A.; Naille, S. Investigation of Phosphate Adsorption onto Ferrihydrite by X-Ray Photoelectron Spectroscopy. J. Colloid Interface Sci. 2013, 407, 95- 101.

58) Yamashita, T.; Hayes, P. Analysis of XPS Spectra of $\mathrm{Fe}^{2+}$ and $\mathrm{Fe}^{3+}$ Ions in Oxide Materials. Appl. Surf. Sci. 2008, 254 (8), 2441- 2449.

59) Takahashi, Y.; Minamikawa, R.; Hattori, K. H.; Kurishima, K.; Kihou, N.; Yuita, K. Arsenic Behavior in Paddy Fields during the Cycle of Flooded and NonFlooded Periods. Environ. Sci. Technol. 2004, 38 (4), 1038-1044.

6o) Pallud, C.; Kausch, M.; Fendorf, S.; Meile, C. Spatial Patterns and Modeling of Reductive Ferrihydrite Transformation Observed in Artificial Soil Aggregates. Environ. Sci. Technol. 2010, 44 (1), 74-79. 
61) Connorton, J. M.; Balk, J.; Rodríguez-Celma, J. Iron Homeostasis in Plants-a Brief Overview. Metallomics 2017, 9 (7), 813-823.

62) O’Rourke, J. A.; Charlson, D. V.; Gonzalez, D. O.; Vodkin, L. O.; Graham, M. A.; Cianzio, S. R.; Grusak, M. A.; Shoemaker, R. C. Microarray Analysis of Iron Deficiency Chlorosis in Near-Isogenic Soybean Lines. BMC Genomics 2007, 8 (1), 476 .

63) Mariotti, M.; Ercoli, L.; Masoni, A. Spectral Properties of Iron- Deficient Corn and Sunflower Leaves. Remote Sens. Environ. 1996, 58 (3), 282-288.

64) Stojanović, M.; Pezo, L.; Lačnjevac, Č.; Mihajlović, M.; Petrović, J.; Milojković, J.; Stanojević, M. Biometric Approach in Selecting Plants for Phytoaccumulation of Uranium. Int. J. Phytorem. 2016, 18 (5), 527-533.

65) Bustingorri, C.; Lavado, R. S. Soybean as Affected by High Concentrations of Arsenic and Fluoride in Irrigation Water in Controlled Conditions. Agric. Water Manag. 2014, 144, 134-139.

66) Rosas-Castor, J. M.; Guzmán-Mar, J. L.; Hernández-Ramírez, A.; GarzaGonzález, M. T.; Hinojosa-Reyes, L. Arsenic Accumulation in Maize Crop (Zea Mays): A Review. Sci. Total Environ. 2014, 488- 489 (1), 176-187.

67) Erbs, J. J.; Berquó, T. S.; Reinsch, B. C.; Lowry, G. V.; Banerjee, S. K.; Penn, R. L. Reductive Dissolution of Arsenic-Bearing Ferrihydrite. Geochim. Cosmochim. Acta 2010, 74 (12), 3382-3395.

68) Brown, J. C.; Von Jolley, D.; Lytle, C. M. Comparative Evaluation of Iron Solubilizing Substances (Phytosiderophores) Released by Oats and Corn: IronEfficient and Iron-Inefficient Plants. Plant Soil 1991, 130 (1-2), 157-163.

69) Pronk, G. J.; Heister, K.; Vogel, C.; Babin, D.; Bachmann, J.; Ding, G.-C.; Ditterich, F.; Gerzabek, M. H.; Giebler, J.; Hemkemeyer, M.; et al. Interaction of Minerals, Organic Matter, and Microorganisms during Biogeochemical Interface Formation as Shown by a Series of Artificial Soil Experiments. Biol. Fertil. Soils 2017, 53 (1), 9- 22.

70) Jin, C. W.; Ye, Y. Q.; Zheng, S. J. An Underground Tale: Contribution of Microbial Activity to Plant Iron Acquisition via Ecological Processes. Ann. Bot. 2014, 113 (1), 7-18.

71) McNear, D. H., Jr. The Rhizosphere - Roots, Soil and Everything In Between. Nat. Educ. Knowl. 2013, 4 (3), 1.

72) Crowley, D. E.; Wang, Y. C.; Reid, C. P. P.; Szaniszlo, P. J. Mechanisms of Iron Acquisition from Siderophores by Microorganisms and Plants. Plant Soil 1991, 130, 179 .

73) Dai, J.; Tang, Z.; Jiang, N.; Kopittke, P. M.; Zhao, F.-J.; Wang, P. Increased Arsenic Mobilization in the Rice Rhizosphere Is Mediated by Iron-Reducing Bacteria. Environ. Pollut. 2020, 263, 114561.

74) Tecon, R.; Or, D. Biophysical Processes Supporting the Diversity of Microbial Life in Soil. FEMS Microbiol. Rev. 2017, 41 (5), 599-623.

75) Küsel, K.; Wagner, C.; Trinkwalter, T.; Gößner, A. S.; Bäumler, R.; Drake, H. L. Microbial Reduction of Fe(III) and Turnover of Acetate in Hawaiian Soils. FEMS Microbiol. Ecol. 2002, 40 (1), 73-81. 


\section{Supplementary Information}

\section{Ferrihydrite Reduction Increases Arsenic and Uranium Bioavailability in Unsaturated Soil}

Arindam Malakar, ${ }^{\dagger}$ Michael Kaiser, ${ }^{\dagger}$ Daniel D. Snow, ${ }^{\S}$ Harkamal Walia, ${ }^{\natural}$ Banajarani Panda, ${ }^{\perp}$ and Chittaranjan Ray ${ }^{\nabla *}$

${ }^{\dagger}$ Nebraska Water Center, part of the Robert B. Daugherty Water for Food Global Institute, University of Nebraska, Lincoln, Nebraska 68583-0844, United States.

${ }^{\ddagger}$ Department of Agronomy, Plant Science Hall 279I, University of Nebraska, Lincoln, Nebraska 68583-0915, United States.

${ }^{\S}$ School of Natural Resources and Nebraska Water Center, part of the Robert B. Daugherty Water for Food Global Institute, 202 Water Sciences Laboratory, University of Nebraska, Lincoln, Nebraska 68583-0844, United States.

${ }^{\|}$Department of Agronomy and Horticulture, University of Nebraska, Lincoln, Nebraska 68583-0915, United States.

${ }^{\perp}$ Department of Earth and Atmospheric Sciences, University of Nebraska, Lincoln, Nebraska 68588-0340, United States.

\# Department of Earth Sciences, Annamalai University, Annamalai Nagar, 608002 India.

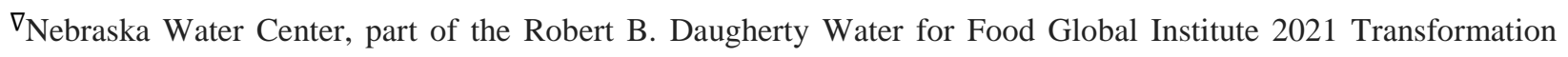
Drive, University of Nebraska, Lincoln, Nebraska 68588-6204, United States.

*Corresponding author email ID: cray@nebraska.edu

\section{Pages S1 to S6}

Figure S1 to S5

Table S1 to S3 


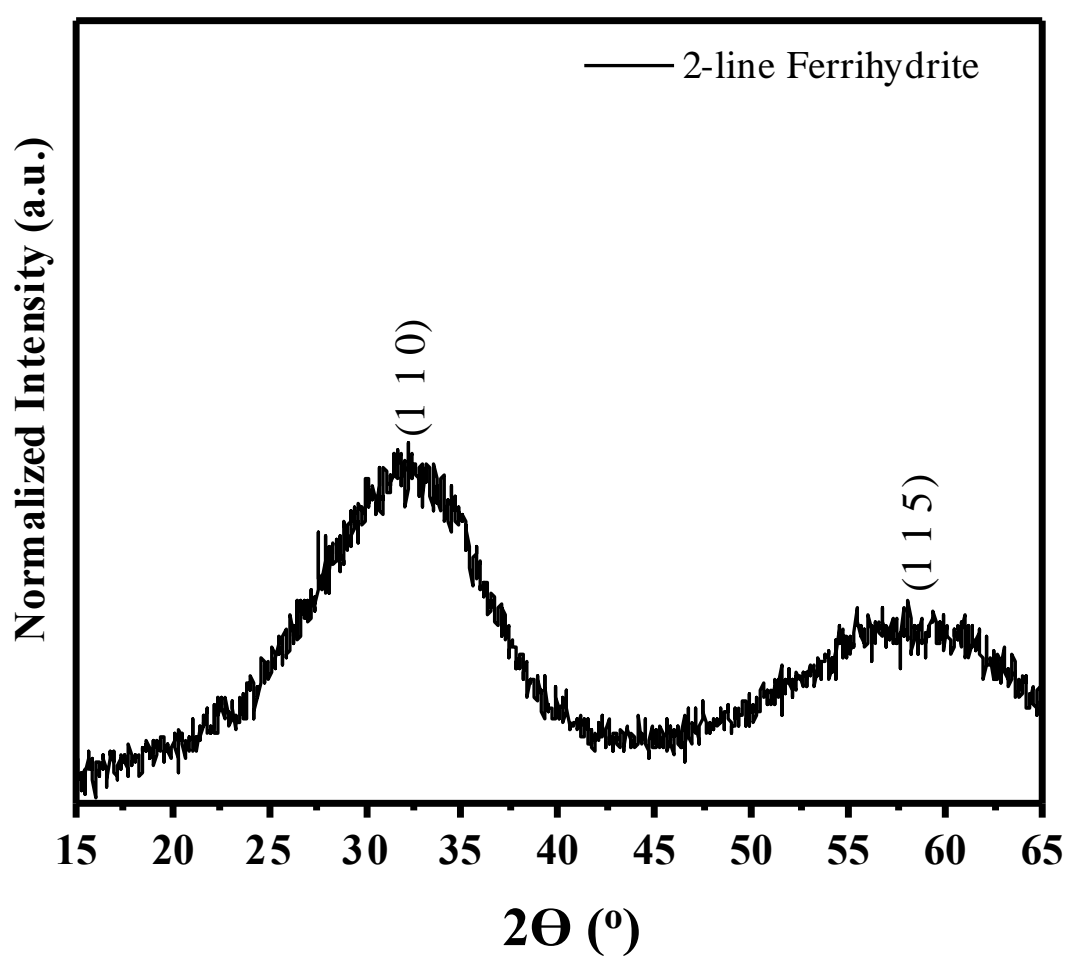

Figure S1. 2-line ferrihydrite powder X-ray diffraction data, matches well with PCPDF\#29-0712.

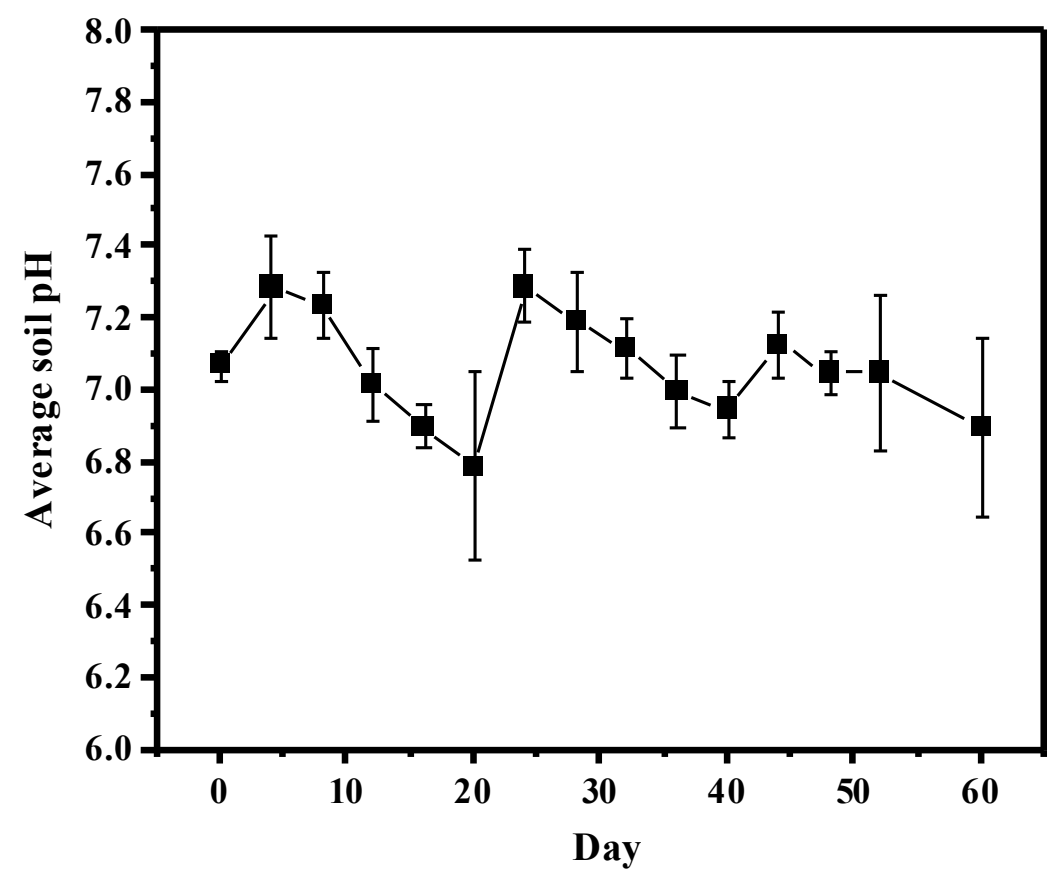

Figure S2. Average soil $\mathrm{pH}$ of all the pots, error bar represents the standard deviation between $\mathrm{pH}$ values. 


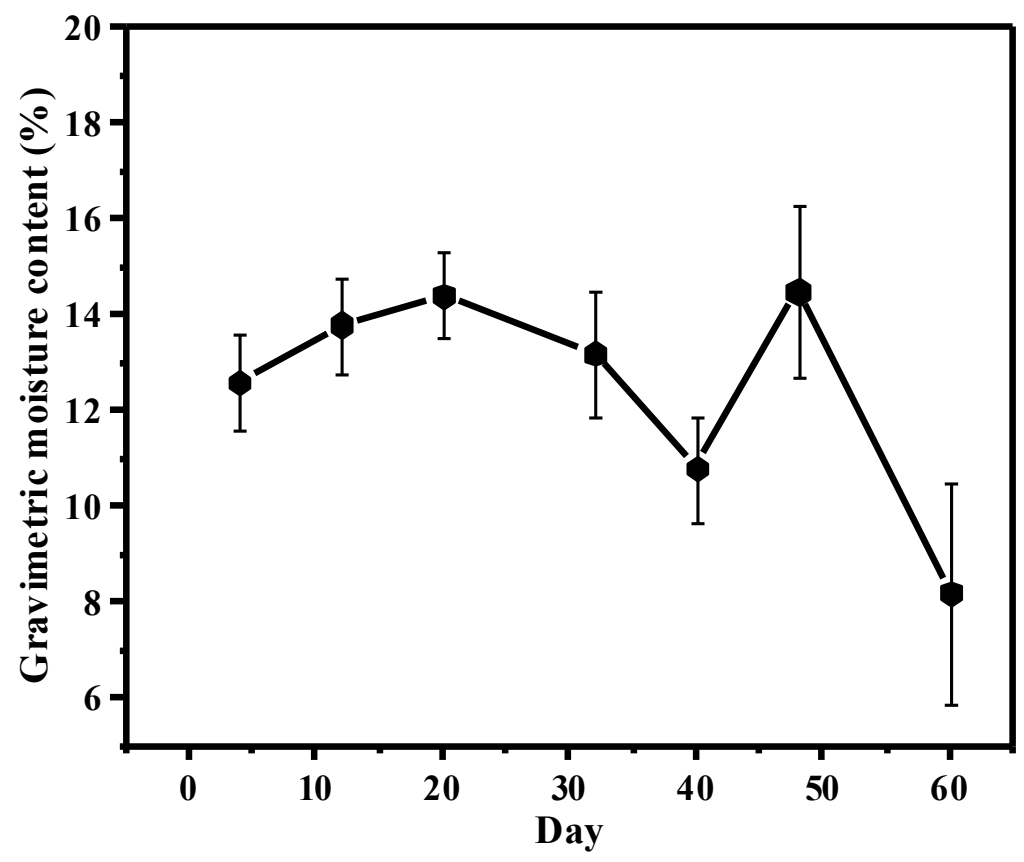

Figure S3. Average gravimetric moisture content of all the pots, error bar represents the standard deviation between gravimetric moisture content values.
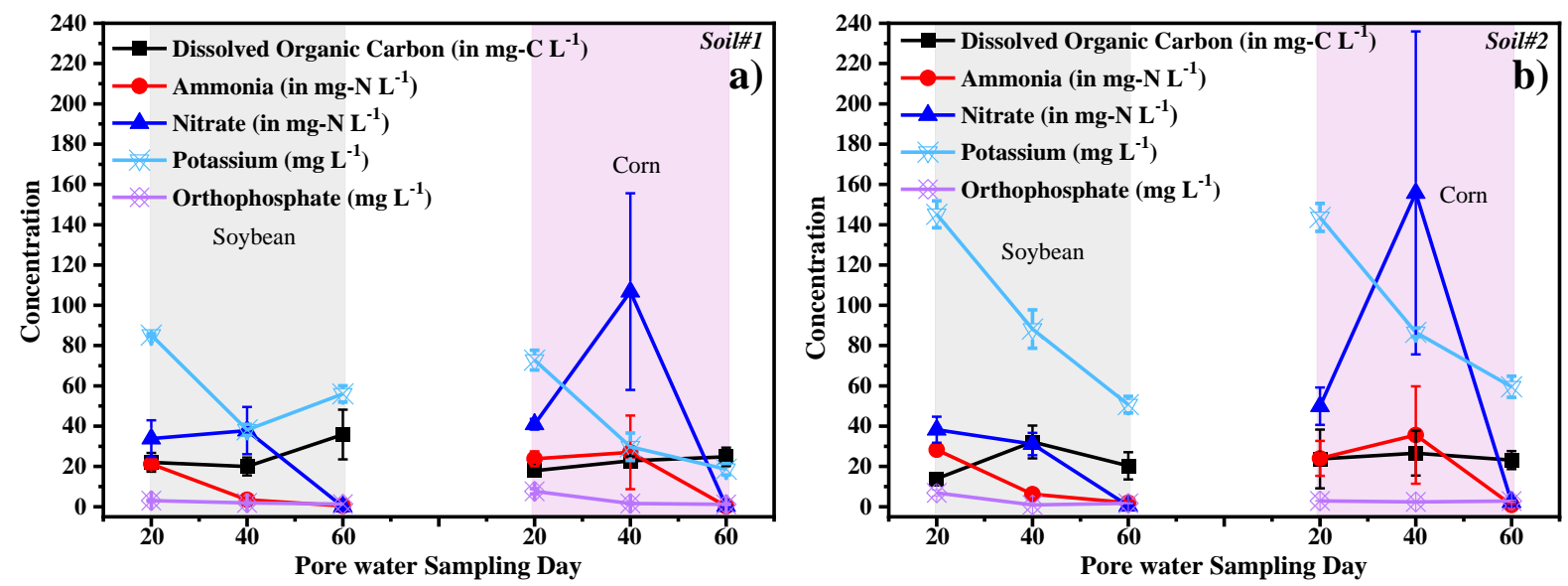

Figure S4. Shows dissolved organic carbon, ammonia, nitrate, potassium, and orthophosphate concentrations in leachate for a) soil\#1 and (b) soil\#2. 

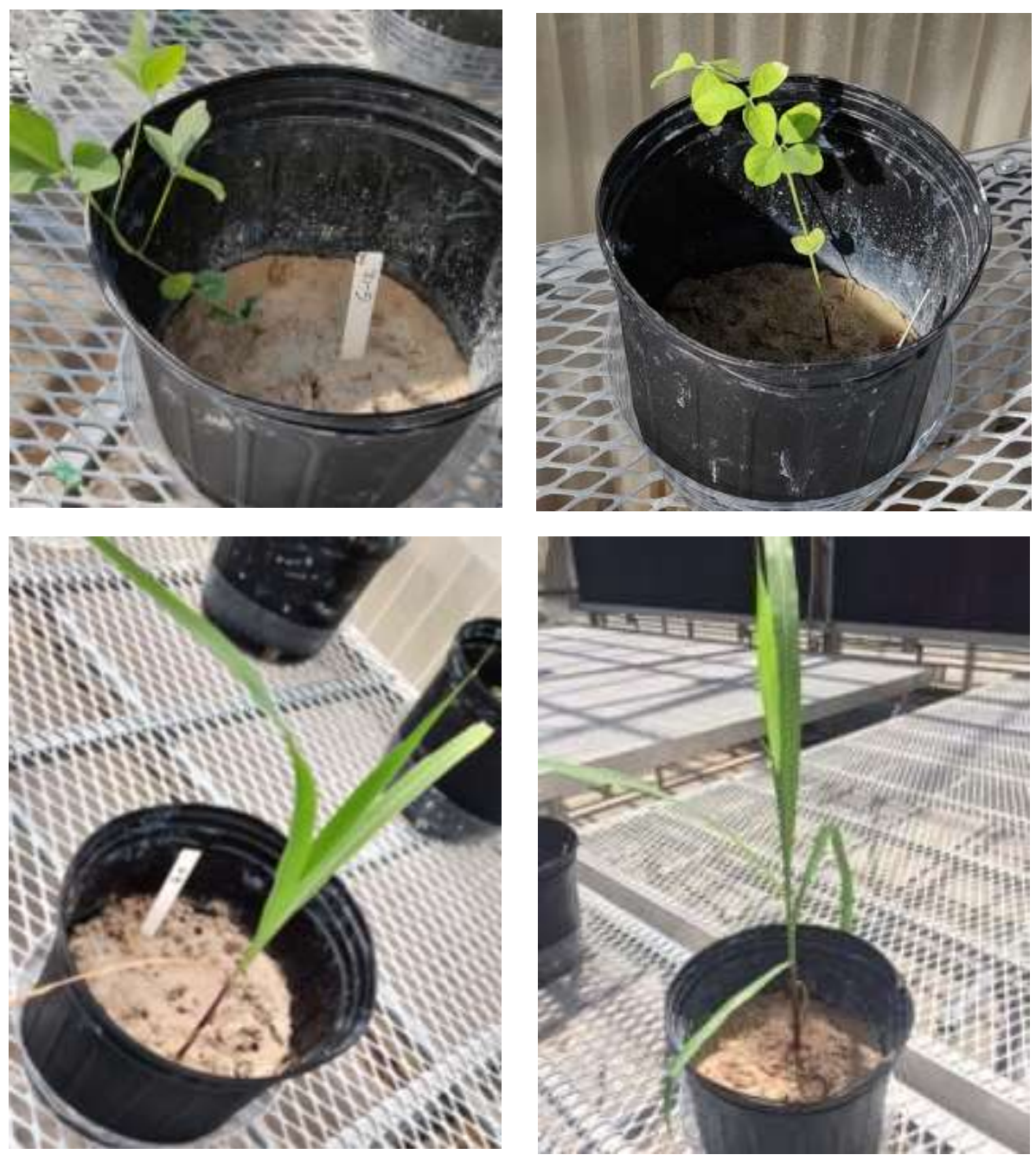

Figure S5. Shows soybean and corn crops in soil\#1 (left) and soil\#2 (right). 
Table S1. $\mathrm{Fe}^{2+}$ values as predicted by chemical equilibrium model compared with experiment value.

\begin{tabular}{|c|c|c|}
\hline Soil 1 & $\mathrm{Fe}^{2+} \operatorname{Exp}\left(\mathrm{mol} \mathrm{L}^{-1}\right)$ & $\mathrm{Fe}^{2+}$ Model $\left(\mathrm{mol} \mathrm{L}^{-1}\right)$ \\
\hline Soybean & $4.6 * 10^{-6}$ & $2.7 * 10^{-5}$ \\
\hline Corn & $2.5 * 10^{-6}$ & $1.5 * 10^{-6}$ \\
\hline Soil 2 & $\mathrm{Fe}^{2+} \operatorname{Exp}\left(\mathrm{mol} \mathrm{L}^{-1}\right)$ & $\mathrm{Fe}^{2+} \operatorname{Model}\left(\mathrm{mol} \mathrm{L}^{-1}\right)$ \\
\hline Soybean & $5.0 * 10^{-6}$ & $1.7 * 10^{-6}$ \\
\hline Corn & $4.4 * 10^{-6}$ & $2.5^{*} 10^{-6}$ \\
\hline
\end{tabular}

Table S2. Saturation index of ferrihydrite mineral as per chemical equilibrium model.

\begin{tabular}{lll}
\hline Soil\#1 & Corn & Soybean \\
\hline Day 20 & -0.87 & -1.03 \\
Day 40 & -0.71 & -0.98 \\
Day 60 & 0.32 & 1.47 \\
\hline Soil\#2 & Corn & Soybean \\
\hline Day 20 & -2.9 & -3.1 \\
Day 40 & -1.18 & 0.01 \\
Day 60 & 0.23 & 1.09 \\
\hline
\end{tabular}


Table S3. Shows iron (Fe) mass balance mean and standard deviation of all replicates for each crop and soil type.

\begin{tabular}{|c|c|c|c|c|c|c|c|}
\hline $\begin{array}{l}\text { Acid } \\
\text { Digested } \\
\text { Initial Fe }\end{array}$ & $\begin{array}{l}\text { Initial } \\
\mathrm{DCB}^{*} \mathrm{Fe}\end{array}$ & $\begin{array}{l}\text { Acid } \\
\text { Digested } \\
\text { Final Fe }\end{array}$ & $\begin{array}{l}\text { Final DCB } \\
\mathrm{Fe}\end{array}$ & $\begin{array}{l}\mathrm{DCB}^{*} \\
\text { Difference }\end{array}$ & $\begin{array}{l}\text { Fe in } \\
\text { leachate } \\
\text { within } 1^{\text {st }} \\
\text { hour }\end{array}$ & Fe in crop & $\begin{array}{l}\text { Unaccount } \\
\text { ed } \\
\text { Or } \\
\text { Converted } \\
\mathrm{Fe}\end{array}$ \\
\hline \multicolumn{8}{|c|}{ (in $\mathrm{mg}$ ) } \\
\hline \multicolumn{8}{|c|}{ Soil\#1 Soybean } \\
\hline $4739 \pm 235$ & $4599 \pm 232$ & $4337 \pm 193$ & $4216 \pm 90$ & $382 \pm 154$ & $1.4 \pm 1.5$ & $2.3 \pm .8$ & $379 \pm 152$ \\
\hline \multicolumn{8}{|c|}{ Soil\#2 Soybean } \\
\hline $6132 \pm 363$ & $5873 \pm 307$ & $5882 \pm 332$ & $5682 \pm 227$ & $245 \pm 85$ & $0.7 \pm 0.2$ & $1.2 \pm 0.6$ & $243 \pm 85$ \\
\hline \multicolumn{8}{|c|}{ Soil\#1 Corn } \\
\hline $4809 \pm 82$ & $4608 \pm 156$ & $4329 \pm 145$ & $4151 \pm 252$ & $457 \pm 160$ & $0.6 \pm 0.2$ & $3.0 \pm 1.2$ & $454 \pm 160$ \\
\hline \multicolumn{8}{|c|}{ Soil\#2 Corn } \\
\hline $6643 \pm 897$ & $6020 \pm 161$ & $6108 \pm 1048$ & $5513 \pm 490$ & $506 \pm 410$ & $0.7 \pm 0.3$ & $3.0 \pm 1.0$ & $502 \pm 410$ \\
\hline
\end{tabular}

"DCB: Dithionite-citrate-bicarbonate method Fe extraction. 